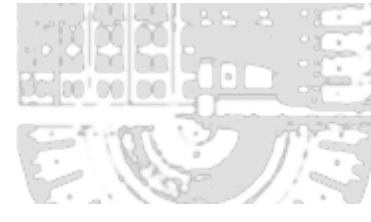 \\ Surveillance \& Society \\ \begin{tabular}{l|l} 
Article & $\begin{array}{l}\text { The "Vigilante Spirit": Bernhard Goetz, Batman, } \\
\text { and Racial Violence in 1980s New York }\end{array}$
\end{tabular}
}

\section{Justin Mann}

The George Washington University, US.

justinmann5@gmail.com

\begin{abstract}
This article details the "vigilante spirit," a term used by New York Governor Mario Cuomo to describe the seizure and execution of state power by Bernhard Goetz in his attack on four black teenagers in December of 1984. It argues that the vigilante spirit is an expression of thoughts, feelings, and practices that produce threats and then assemble the tools it deems necessary to combat them. It further argues that the vigilante spirit, expressed by Goetz in his attack, was also encoded in various cultural texts produced in the 1980s and uses Frank Miller's The Dark Knight Returns as an example. By reading these two case studies together, it seeks to explain the cultural politics that underpinned racial violence in the 1980s.
\end{abstract}

\section{Introduction}

"When people feel they are not adequately protected, the force of the argument that they should not take their defense into their own hands diminishes."

The Washington Post, 28 December 1984

"Gotham City Belongs to the Mutants."

Frank Miller, The Dark Knight Returns

In August of 1985, The Comics Journal, a popular press journal written by and for fans of comic books and graphic novels, published a long interview with graphic novelist Frank Miller, one of "the most powerful creators in mass-market comics," by its estimation (Thompson 1985). Miller's power, the Journal explained, stemmed from his ability to captivate his audience and the industry, "commanding (its) attention, respect, and weighty contracts." In the course of the interview, which was conducted in Miller's Hollywood apartment, he explained his relocation to Los Angeles from New York City and related this move to his forthcoming interpretation of the iconic superhero Batman. "When I left New York," he said, "I had come to regard it as an emotional, psychological, and spiritual dead end." The regularity of "crime and unending hostility" naturally resulted in the normalization of "ungentlemanly" and "uncivilized behavior." "One Bernhard Goetz was enough,” Miller remarked, “though I'm amazed there aren't more people doing what he did." Rather than distance himself from Goetz, the gunman who shot four black teenaged boys on New York City subway, Miller signaled an element of sympathy for him; Goetz helped him realize that New York was hopeless. Miller's remarks on the City's descent into crime and decay 
segued into a discussion of his work, and specifically to an assessment of the forthcoming Dark Knight Returns mini-series (1986). Miller's real life experience with the pervasive and oppressive force crime exerted on New Yorkers translated to "a more realistic" representation of Gotham City. In writing The Dark Knight Returns, Miller aimed to clarify superheroes' "relevance" to the cultural imaginary. Both Miller and Thompson used the term "realistic" to denote a narrative and representational strategy that allowed city and hero to transcend and transgress the boundary of the page in order to speak to relevant issues of 1980s urban life.

As Miller suggested in the early moments of his interview, Bernhard Goetz best captured the problems of urban life in 1980s New York. Bernhard Hugo Goetz, a middle-aged, white electrician, shot four black teenagers after they asked him for money, then he escaped into a subway tunnel and fled to New Hampshire. Governor Mario Cuomo castigated Goetz for his actions and the mistrust of institutional law enforcement they symbolized. He went on to condemn public support of Goetz, which he termed the "vigilante spirit" (New York Times 1984a). People throughout the United States, and New Yorkers in particular, sided with Goetz, claiming the state was incapable of maintaining law and order and lauded Goetz for protecting himself (Schanberg 1985a, 1985b). Some officials like Cuomo instead viewed the "vigilante spirit" as a problem of governance and erosion of the rule of law, a "dangerous" turn in contemporary ideas about criminal justice and procedure (New York Times 1984a). In his interview with the New York and New Hampshire police, Goetz explained his actions in social terms, expressing the concern that, "someone else on the subway system," might have been "butchered" (Caws and Shear 1987). Miller's Batman similarly deputizes himself as an extralegal agent with the capacity to act in lieu of state institutions meant to enforce law and order. Both figures represented an assumption of power intentionally reserved for the state, bypassing the limitations on the use of that power in the name of protection. My analysis, it must be said, should not stand as justification for state violence. On the contrary, what Goetz and Batman ultimately reveal is the very danger of incorporating the vigilante spirit into the machinations of policing and law enforcement.

The "vigilante spirit" did not merely denote the public support for Bernhard Goetz, nor did it only apply to the similarities between Goetz and the popular culture avengers of urban crime to whom he was frequently compared. The vigilante spirit also encompassed the complex networks of thoughts and feelings that facilitated the turn away from state power that crystalized in the 1980s. Emerging as a direct reaction against integration efforts of the mid-century, the manifestation of the vigilante spirit in the 1980s relied on a racialized worldview as it simultaneously insisted on the immateriality of race, an ideology that has been termed "colorblind racism" (Alexander 2012; Bonilla-Silva 2014). The vigilante spirit, as it appeared in this particular moment, circumscribed white city-dwellers as vulnerable subjects besieged by black and brown criminals. It further linked black criminality to ailing inner-city infrastructure and ineffective institutional power. White vigilantes, allegedly fearing for their lives and for the lives of their fellow white citizens, wrested the justified use of force out of the hands of state authorities and wielded it without fear of retribution from prosecution. The assumption and expression of police power performed by Batman and Goetz required a hypersensitive mechanism of surveillance, surveillance Cuomo and others termed vigilance. The vigilante spirit thus enabled Goetz and others to assume that black and brown city-dwellers were threats, always-already beyond the capabilities of the police and the courts. It further endowed them with the extraordinary power to commit acts of extreme violence without the fear of prosecution.

The vigilante spirit is one example of what I term "security imaginaries." Security imaginaries relate and translate imagined sources of insecurity as they exist in culture and discourse into real world manifestations of security policy and practice. This process is not unidirectional; security policy and practice also inevitably participate in the construction of threat in imaginaries as well. Looking to speculative fiction like The Dark Knight Returns reveals that security itself is often speculative. In formal and informal expressions alike, security relies on a network of interrelated ideas and feelings about danger 
and safety, ideas that are often exaggerated and hyperbolic. Speculative fiction ${ }^{1}$ is uniquely suited for examining imaginaries because it can most ably access these hyperbolic qualities. Security imaginaries are ideological constructs. In his classic formulation of "Ideological State Apparatuses," Louis Althusser explained, "What is represented in ideology is therefore not the system of the real relations which govern the existence of individuals, but the imaginary relation of those individuals to the real relations in which they live" (Althusser 1970 in Žižek 2012; see also Jameson 1981; Wegner 2009). Security, often understood to be a fact of real life, can instead be understood as a way of engaging with a set of imaginary possibilities that correspond to vulnerability to, or protection against, danger and harm. The production of threat in both real and imaginary realms relies on the act of surveillance. In Goetz's case, the practice of surveillance rendered a group of young black boys as suspicious, cast the passengers on the train including Goetz himself as innocent, and resulted in the "reasonable" use of force against those boys (Sullivan 1989). This reading of vigilance frames Goetz as a figure whose interpellation into the system of racial violence was produced by external power structures that populate his world; we are meant to assume he was powerless to resist.

Yet both Miller and Goetz chose to explain themselves in affective rather than ideological terminology. Thus, security imaginaries also help decode the intricate and nebulous relationship between the emotional and ideological worlds. Raymond Williams, for example, would catalogue Miller's language as a description of a "structure of feeling" (Williams 1971). Williams explains structures of feeling as translational devices that allow thought and feeling to be legible to each other. In her discussion of "statistical panic," Kathleen Woodward further reveals that Williams' concept fuses thought and feeling "and does not separate them." Furthermore, structures of feeling reveal "new and emerging social formations" (Woodward 2009). A structure of feeling, in both Williams' and Woodward's conceptions, has particular spatial and temporal valences that enable scholars to track the elision of thought and feeling through specific epochs. Recent scholarship has augmented the study of emotions by suggesting that they are public, and therefore political forces that have profound effects on the social fabric (see for example Anker 2015; Berlant 2011; Butler 2006; Masco 2014; Puar 2007). This scholarship also brings to bear the importance of everyday life on matters of politics. Both Miller and Goetz related the importance of their daily experiences with crime. As a structure of feeling, the vigilante spirit schematized the host of thoughts and feelings that comprised the experience of city life in the early 1980s, and made reasonable the conclusion that the state had failed and that individual action was necessary to secure safety.

\section{The Vigilante Spirit}

Vigilante justice certainly existed before the 1980s. Surveillance and physical violence have long been paired in order to maintain white supremacy, though the specific quality of their practices has changed throughout time. Under slavery, for example, surveillance was a bulwark against escape and association, and criminal statues against both ensured that American courts would not protect slaves who attempted either, effectively collapsing blackness into criminality (see for example Browne 2015; Gordon 2008; Hartman 1997; Holland 2000). In the aftermath of the abolition of slavery, lynching emerged as the pervasive and systematic means of maintaining white supremacy; legal prohibitions against physical violence did little to protect blacks against abuse and murder, especially when members of violent mobs often included police chiefs and judges who were supposed to protect all people from violence. Drawing forcefully on the conflation of blackness with criminality, lynching cemented the idea of the black (male) criminal in the hearts and minds of the American people. High profile $20^{\text {th }}$ century lynching including the murders of Emmett Till in 1955 and four freedom riders in 1964 contributed to a more favorable view of

\footnotetext{
1 What precisely comprises speculative fiction is a matter open for debate. James Gunn convincingly describes science and speculative fiction as the fiction of change. To this, I add that speculative fiction reveals precisely the ideal or imagined world of ideology, one in which the barriers of plausible are effaced in favor possible (see Gunn and Candelaria 2005; Rieder 2010).
} 
integration and civil rights legislation. Yet the successes of the civil rights movement also engendered a backlash. White Americans reshaped challenges to white supremacy by abnegating the political investment in racial difference in favor of colorblindness. Coupled with mass incarcerations - which mobilized notions of black criminality constructed during slavery and promulgated during Jim Crow in order to sanction the warehousing of black bodies in prisons - colorblindness eroded progressive social programs designed to undo the political and economic legacies of white supremacy. The irony of such an ideology is that its believers often mobilized racializing language in the service of subverting conclusions that racism was operational at all (Alexander 2012; Hale 1998; Wacquant 2009).

The vigilante spirit, as it appeared in the 1980s, bore all of this history. In its manifestation in both Goetz's attacks and Miller's comic, it made legible a broad public sentiment marked by feelings of helplessness and abandonment that dominated city life in the 1980s. It neatly corroborated ideas about the failures of government that featured prominently in New Right ideologies. Rather than trigger renewed hope for the possibility of state intervention, the vigilante spirit instead conjured up a vision of a failed state, atrophied beyond repair, a "government" incapable of fulfilling "its most basic responsibility: public safety"(New York Times 1985b). Goetz made clear that "the law on that subway car on Dec. 22 was in no one's hands" (New York Times 1985b; see also McGirr 2015; Schulman 2008; Troy 2005). Populating this failed state were mischief-making hoodlums looking for easy targets, but also rapists and murderers, "marauding lawbreakers" in Senator Alphonse D'Amato's terms (D'Amato 1985). These "lawbreakers" were almost always imagined to be black or brown. Through the vigilante spirit, the pervasive feeling of abandonment enabled the assumption of power ordinarily reserved for state institutions. At the forefront of these powers was surveillance, a vector of power that was central to the racial construction of crime and the city. As scholar John Fiske has argued, "Surveillance is a technology of whiteness that racially zones city space by drawing lines that Blacks cannot cross and whites cannot see" (Fiske 1998). Surveillance was thus a central component of the vigilante spirit as it emerged in the 1980s because it structured notions of space and belonging through violent encounters with police and individual citizens alike. It also relied on a set of sensibilities that circuited through the longstanding yet unstable and asymmetrical binary between public and private life. A zone like the "ghetto" was, and is, constructed as public space, but public space delimited by the power of surveillance barring ingress and egress for black people living inside it (Fiske 1998). Through the vigilante spirit, private citizens enforced and reinforced the boundaries of that space. Further, the invisibility of the boundaries between these zones naturalized the idea that people of color were the only reason for urban decay. Unseen by this ideology was the devastation retreating infrastructure wrought as it sapped poor communities of much needed resources. In Patricia Williams' formulation, the "privatization of public space" led directly to "spirit murder," a self-perpetuating loop in which blacks were blamed for their inability to escape the cycle that trapped them in the first place (Williams 1991).

The proliferation of the vigilante spirit in the context of colorblind racial ideologies compounded the imagined links between blackness and criminality. Importantly, this conflation often led directly to violent encounters between black and white people, the deadly results of which were often naturalized as "reasonable" and therefore protected by the law. Vigilance thus emerged in the Goetz case, the graphic novel The Dark Knight Returns, and elsewhere, as the implicit character of racism.

\section{"You Don't Know Violence Like I Do"}

Three days before Christmas in 1984, Bernhard Hugo Goetz shot four young black men-Troy Canty, Barry Allen, Darrell Cabey, and James Ramseur - at close range on a New York City subway in the middle of the day. After the shooting, Goetz "disappeared" into the shadows of the subway tunnel, and made his way to New England (The Washington Post 1984a, 1984b). Along the way, he disposed of his thirty-eight-caliber handgun. After eleven days, he walked into a New Hampshire police station and presented himself as the suspect police were looking for in New York. He was taken into custody and 
gave a videotaped confession in which he admitted to shooting four black teenagers intending to kill them (Sanger 1984; Van Biema 1985). The apparent pulpiness ${ }^{2}$ of this scene cannot be understated: when asked for money, Goetz "calmly" drew a gun and shot two young men, saying, "I'll give you five dollars" (The Washington Post 1984b). Then he shot two others as they attempted to flee. After refusing to turn over his gun, he dissipated in the darkness of the subway tunnel (Chambers 1985a; The Washington Post 1984b).

In the reports of Goetz's actions that emerged in the days and weeks after the incident, many offered support not for the victims but for Goetz. A guard at the New Hampshire jail that held Goetz after his arrest, for example, reported that he was "emotionally drained [...] and apologetic" (Washington Post 1985). Furthermore, the police hotline designed to provide police with information on Goetz's whereabouts instead received many calls praising his actions (Sanger 1984; The Washington Post 1984b). Goetz was hailed as a "folk" hero in the spirit of Charles Bronson's character Paul Kersey in the film Death Wish (Giglio 2014; Sanger 1984; The Washington Post 1984a). The popular press wove a rich tapestry of racialized language in the service of describing the events themselves and their links to patterns of crime and criminality in the post-industrial urban landscape. The question of whether the attacks were racially motivated hid "just beneath the surface," in one critic's estimation (Sanger 1984). In contrast, Washington Post columnist Henry Mitchell condemned the "near-unanimous" and hasty public support for Goetz in the immediate aftermath of the shooting, support that he called "the Gut verdict" (Mitchell 1985). In his view, the public's misguided praise of Goetz was linked to the visceral knowledge of fear that accompanied city life. This knee-jerk reaction might otherwise be understood as a structure of feeling, a way of translating feelings about the failure of state regulators and police forces into actionable ideas. Goetz's imagined insecurity on the subway contrasted with Governor Cuomo's own imaginary of the proper response to crime on the subway. Cuomo, who argued in favor of a "very firm, even, tough criminal justice system," militated against the vigilante spirit, but this was ultimately to no avail (The Washington Post 1984a).

Early reporting on the attack, flight to New Hampshire, and eventual arrest consistently described Goetz as "mild-mannered" and "bespectacled." Many included details about his proclivity for electronics (Geist 1985; Hornblower and Tsiantar 1985; Van Biema 1985). Although "New York's political leadership" was at first "uncompromising in its insistence that the mystery gunman (...) would be brought to justice," both Mayor Koch and Senator D'Amato eventually aligned themselves with the majority who sided with Goetz. Even "liberals," imagined to be more sympathetic to the victims, "wondered out loud whether the man wasn't right to take the law into his own hands" (Sanger 1985). Few rejected the premise that Goetz was a "sympathetic" figure, whose actions were, at least in part, justified. Instead, they produced an image of Goetz that was relatable, casting him as a downtrodden Everyman beleaguered by the rampant crime that plagued the city's subways. Descriptions of Goetz's appearance at his arraignments included details about his blue jeans and brown leather coat, his "pale" and "tired" appearance, his calm demeanor, and his silence (Chambers 1985a, 1985b, 1985c). On its April 8, 1985 cover, TIME Magazine chose to represent Goetz in the same clothes, emerging from a $14^{\text {th }}$ street subway station into a dark New York City night, adjacent to three headlines including, "Rising Fear of Violent Crime" and "Public Anger At the Justice System." Goetz climbs out of the illuminated subway station instead of escaping into the darkness of the tunnel. The failure to accurately display the terms of Goetz's escape is worsened by the fact that Goetz, a perpetrator of subway crime, is seemingly set apart from his criminal actions. The rising crime the headline heralds does not, apparently, include shooting four teenagers, not even when two of them have their backs turned. Additionally, Goetz's casual posture belies the headlines that surround him; he seems neither afraid nor angry, but rather comfortable. Whether consciously or not, the cover art also evoked a

\footnotetext{
2 Pulp here refers to genre fiction such as science fiction, fantasy, or detective fiction characterized by formulaic plots. Pulp fiction played a central role in the development of contemporary graphic novels and other forms of speculative fiction (see Wright 2003). Throughout I use the term to refer to the style of the graphic novel (see Gunn and Candelaria 2005; Rabinowitz 2002.)
} 
sense of certainty. The black surround that frames the image of Goetz also serves as the background for the headline text. Devoid of color, the cover represents the case in black and white terms, aligning Goetz with the angry public, malcontented with the justice system, and fearful of "rising [...] violent crime." Though many lamented his actions and the vigilante spirit he embodied, few, if any, could find the right language to reject them. Goetz tapped into the security imaginary that attached to the inner city and construed white urbanites as besieged by hordes of black criminals. He drew upon its salience, enshrouding himself in the protective armor of reasonable action, action made reasonable because of the fear people felt.

Characterizations of the four young victims were less sympathetic. They were often classified under the ominous descriptor "youths," cast as menacing "hoodlums" whose intentions were surely to rob Goetz (New York Times 1985b; Mitchell 1985; Banzhaf III 1985). The presence of "sharpened screwdrivers" further implicated the victims in their own assaults, though these "weapons" do not appear to have been brandished and were likely not visible to Goetz at all (Chambers 1985a; Sanger 1984; Hornblower and Tsiantar 1985). Nevertheless, the presence of the weapons further demonstrated to the public that the boys, and not Goetz, were dangerous. Judge Alan Marrus issued a bench warrant for Troy Canty, one of the victims, to appear in court, despite his knowledge that Canty was in the hospital recovering from his wounds. Canty, the Judge explained, had an "extensive" criminal record and "pose[d] a danger to the community." He allegedly stole fourteen dollars in quarters from an arcade game (New York Times 1984b). Other common monikers used to describe the four black teens included "thugs," "punks," "hoods," and "criminals" (Mitchell 1985; Schanberg 1985b). In short, the teens figured into the drama only as faceless antagonists. While much was made of the affective responses from officials, New Yorkers, and others across the country, the possibility of sympathy for the black victims of Goetz's attack was all but foreclosed. The Washington Post even reported that the mother of Barry Allen, one of the victims, felt "sympathetic toward [Goetz]" in an effort to demonstrate that "the controversy [...] over the shooting has not been along racial lines" (Hornblower and Tsiantar 1985). Yet as Charles Cobb explained in The Afro-American, "Mr. Goetz responded [to allegations that he 'instigated the incident'], saying 'It's kind of ridiculous to consider that someone-let's say in my position - carrying things, would start up with 3 [sic: four] blacks in the subway" (Cobb 1985, emphasis in original). Goetz's abandonment of raceneutral descriptions demonstrated the racism that propelled him into action. To Cobb, this evidence should have been the cornerstone for the case against Goetz. Police Commissioner Benjamin Ward, the city's first black police commissioner, also viewed the case in racial terms. Ward explained that the public support for Goetz was not surprising, likening that support to a lynch mob (Purnick 1985; see also The New York Times 1985a).

Goetz never testified on his own behalf. Instead, his defense attorney argued that his recollections were a "fantasy," and that he did not shoot Darrell Cabey after pronouncing, "You seem to be doing alright, here's another" (Caws and Shear 1987). Ultimately, the grand jury found him not guilty of attempted murder, assault, and reckless endangerment. The presumption of Goetz's innocence extended far beyond the parameters of his trial, but influenced his conditions of punishment. Rather than serve time for assault or attempted murder, Justice Crane sentenced him to a one-year term for illegal possession of a handgun, a term he served in the Riker's Island hospital. He was sequestered away from the general population to "protect him from other inmates." He also had to face a $\$ 5,000$ fine. At his sentencing, Goetz proclaimed his incarceration to be unjust. He argued that his prosecution indicated the "deterioration in society," and that people "needed to be protected from criminals." Incarcerating him was a miscarriage of justice, according to his attorney, because it would amount to locking up an innocent white man, while violent criminals terrorized the people of New York (Sullivan 1989). When Frank Miller explained his sympathy for Goetz in the opening moment of his Comics Journal interview, he also tied urban city-dwellers' feelings of oppression and fear to the need for vigilante justice. Miller inscribed this dismal view of the city in his graphic novel, and then set Batman as the city's night watch. In the section that follows, I offer 
a close reading of Miller's The Dark Knight Returns in order to excavate the latent sensibility of racialized crime that saturates it.

\section{A Darker Knight}

Safely enthroned within the Batmobile's protective hide, the Dark Knight observes the monstrous leader of the Mutants, a gang terrorizing Gotham City (Miller 1986). Surrounded by the various levers, screens, nobs, and dials that control the Batmobile's complex machinery, Batman surveys the villain through his periscope. In his left hand, Batman clutches the throttle. In his right, he grips the weapons systems, fingering the trigger and contemplating, "blast[ing the Mutant Leader] from the face of the earth." Cast in the shadow of an illuminating screen, the gadgets comprising the vehicle's many systems appear similar to Gotham City's jagged skyline. Batman looms above these contours, his panoptic view on display. Smaller circular frames depicting the Mutant Leader's sharp fangs and bulging muscles punctuate the right side of the page, while the bottom left corner frames a close-up on Batman's face. These frames bring the object of Batman's gaze into the reader's view; as he narrates his perspective, Batman identifies and emphasizes the Mutant Leader's features that mark him as an object of simultaneous loathing and desire, his "physical prime."

Frank Miller's 1986 graphic novel, The Dark Knight Returns, is a prime example of the cultural expression of security imaginaries in general and the vigilante spirit in particular. Miller pioneered the transformation in 1980s comics that aimed for a more realistic tone (see Fawaz 2015; Thompson 1985; Wright 2003). In his work on Batman, Miller strove to reframe the hero as a serious and stalwart populist, who used his abundant wealth to defend the rights of the beleaguered inhabitants of Gotham City (Thompson 1985). In doing so, he attempted to cast aside Batman's campy legacy in favor of a grittier, pulpier atmosphere and tone. First published in 1939 and appearing as a flagship title for DC Comics throughout its publication history, Batman has been a complex figure with a complex history whose resurgence in the 1980s was due in large part to Miller's grittier tone and virtuosic art. Batman emerged into the pulp world of 1940s print comics as a new kind of superhero, wholly human but incredibly athletic. Bill Finger, one of the comics' original scribes, intended for Batman to be, "a combination of Douglas Fairbanks, Sherlock Holmes, the Shadow, and Doc Savage as well..." (Steranko 1970 in Kane and Andrae 1989). In the post-war era, Batman's dark tone brightened to accommodate the Technicolor world of the 1950s. Batman and Robin became full-fledged members of the consensus culture when they were deputized into the Gotham City police force, eventually even entering the world of mod-culture in their campy television serial starring Adam West as the Caped Crusader (Wright 2003). Frank Miller's Dark Knight was thus an antidote to the steady increase in the comic's silliness, returning the title to its origins. Miller's retelling has left a deep impression on the brand; both the 1989 Tim Burton film Batman and Christopher Nolan's Dark Knight Trilogy $(2005,2008,2012)$ drew on the atmospheric, tonal, and narrative elements Miller introduced in The Dark Knight Returns.

Issued in four installments, The Dark Knight Returns tells the story of a middle-aged Batman who once again dons the cape and cowl after a ten-year hiatus, a hiatus brought on by the untimely death of his sidekick Robin. Bruce Wayne resumes a life of crime fighting in response to the rising threat of violence from an urban gang called the Mutants. In this story, Bruce Wayne has an amicable relationship with Gotham City's retired police commissioner Jim Gordon. Both Wayne and Gordon are presented in opposition to institutional forms of power - the police force, the mayor's office, the military, and the news media are all corrupt and untrustworthy. Miller's series tracks Batman as he comes to terms with many of the social and political failures historians associate with the 1980s. From a decrepit urban landscape to crooked politicians, Miller's text illuminates the reactionary impulses that animated the vigilante spirit as a security imaginary in the 1980s, linking a broader ethos of privatization to the instantiation of security in practice. The representational and semiotic strategies that appear in the graphic novel further explain the centrality of race to the cultural life of the vigilante spirit and security imaginaries. 
Miller's desire to depict a more "realistic" Batman - to take Batman back to his roots in the pulpy, noirinflected world of urban crime drama - relied on a decaying city that featured prominently in discourses about crime and criminality in the 1980s. Where Miller saw a world that was, "good and fucked," journalists remarked on the "desperate society" (Thompson 1985; Powell 1985). The anxiety that Miller inscribed in the inhabitants of Gotham bespoke the same sense of desperation, at times quiet and at times raging, that illustrated people's responses to the Goetz case. A feature in The Washington Post on the New York Subway described support for Goetz as "understandable" (The Washington Post 1984a; see also The New York Times 1985a). It used the rhetoric of languish and decay to describe the subway, which, "had fallen on hard times. Much of the equipment is old and constantly breaking down. The cars and the stations are filthy, covered with graffiti and littered with trash [...] but the most frightening element is the crime." The subway, ailing as it was, suffered from a lack of attention; the old and unfit equipment made it more susceptible to the predation of criminals who "frightened" commuters who relied on the subway for transport. In this scheme, the subway served as synecdoche for the city, a subterranean tumor symptomatic of a metastasized over-world. The Dark Knight Returns succinctly depicts this metaphoric relationship. In a short vignette in the middle of the graphic novel's second issue, two members of the mutant gang brutally murder Margaret Corcoran, a down-on-her-luck bystander who serves no narrative function other than to die. The Mutants kill her by placing a bomb in her bag. Margaret clings desperately to her purse after retrieving it from the Mutants, protecting the set of paints she has purchased for her son. This short scene serves little narrative purpose. It does link the Mutants to the criminal activity many commentators indicated plagued the subway, the same activity that allegedly preconditioned Goetz to make his attack. Both the subway station and the train are covered in brown graffiti. The window and door glass of the car are cracked with abuse. None of the passengers in the car attempt to help Margaret. Though it is extraordinarily violent, the scene is also remarkably mundane. It is importantly the regularity of the violence that makes the scene exceptional and which marks the condition as an expectation.

Miller's representation of the city further drew on the decrepit terms that many used to describe New York. An early establishing frame presents the city in the throes of a heat wave, simmering as fog rises feverishly over the tops of the buildings. The backlit buildings of Gotham's downtown area appear blackened, while the leading lines from the roofs draw the viewers eye toward the City's dark heart. Dave, a morning show host, tells his co-host Lola that there is, "No relief in sight." She replies that the heat has, "sparked a wave of civil violence" caused by the Mutant Gang. Here as in the subway scene, Miller casts the Mutants as simultaneously bored and depraved, everyday criminals and supervillains at the same time. Miller insists on distinguishing those poor Gothamites with little or no access to public services, like Margaret Corcoran in the above example, from members of the Mutant Gang, whose savagery is untethered to any coherent cause. In general, then, Miller's distinction is one of innocence. Margaret Corcoran, Joyce Ridley and her son Kevin (two other victims), and the citizens of Gotham more broadly, are the innocent victims of the Mutant's reign of terror.

As the central character of the graphic novel, Bruce Wayne's situation in this urban world is of paramount importance. On the tenth anniversary of Batman's disappearance, Bruce Wayne walks down one of Gotham's crowded city streets. The pedestrians around him are colored in drab blues, grays, and browns. Two Doomsayers pass by him, heralding the end of the world. Bruce, by contrast, is depicted in crisp dark lines; the sharp angles of his suit separate him from the surrounding rabble. His bodily mass is evident beneath the fabric, which stretches over broad shoulders and thick legs. As he steps out onto the curb, he reflects on Batman's absence from the city, calling himself, "a zombie. A Flying Dutchman. A corpse." Bruce draws himself into a comparative association with the city itself. He has left it bereft because he himself is bereft, mourning the death of his partner. But his bereavement is a temporary condition, for unlike the ailing city, whose inhabitants fade into the background, Bruce is a man of action. Even his analogies belie a sense of forward motion that subtends his own feelings about his implication in the rehabilitation of the ailing city. Neither the zombie nor the Dutchman are inert; both are mobile, animated 
creatures that act on the world. Even his framing contrasts the frozen state of the denizens behind him. His tie flaps in the streaming wind that blows the garbage around him. Though his head is cast down, he steps forward into the street along the axis that connects the eye to the page. Indeed, framed this way, he projects an almost teleological futurism that, coupled with the surrounding frames, forewarns of his immanent return to the life of crime fighting.

Wayne finally does come to rest in the bright glow of a streetlight. Two members of the Mutant gang try to mug him but beg off after one of them suspects that Bruce might "be into it." The two-page frame invokes the conventions of film noir, using a muted palette and low-key lighting to invoke the sense of danger that propels Bruce into action. The attempted mugging takes place in a pool of bright light, threatening an inversion of Fiske's paradigm of surveillance. Yet Bruce Wayne's hypervigilance forestalls the attack and restores the subject-object dyad to its rightful orientation: though the reader observes Bruce, she really observes Bruce observing criminals, presenting himself as a target in order to reveal the Batman within. Over the course of the spread, the reader is positioned as onlooker, with a scatter-shot collage of views including Bruce's face, his feet, and his torso. Like the previous page, these shots subvert his assertions that he is a walking corpse; on the contrary, his robust body strains against the confines of the suit, longing for the attack that might unleash the "creature writh[ing] and snarl[ing] in his gut." If the long shot of the city establishes the setting as stifling and unrelenting, the spread works to determine the mood and tone of the ensuing drama and simultaneously signal some of the components that comprise the vigilante spirit. Just as "noir's tales of murder and passion, of ordinary lives gone hopelessly astray, of psychopathic criminals preying upon innocent citizens and of conniving women seducing gullible men," signaled to Eric Avilla, "a distinct loss of confidence in the vitality of the American dream," in the aftermath of World War II, Miller's mobilization of similar tropes signaled a distinct loss of confidence in the virility of the American state in the 1980s (Avila 2004; Rabinowitz 2012). Miller thus eliminated the "conniving" femmes fatales from his narrative matrix in favor of maniacal men hell-bent on the destruction of society at large.

Lighting was a key strategy directors used to racialize characters, "blackening" both "whites who broke the law, but also those who transgressed socially prescribed boundaries" (Avila 2004). The low-key lighting that encircles Bruce in street lamp's pool also casts the two Mutants in shadow, "blackening" the entirety of their visages. This technique is also frequently used in the depiction of the tapes the Mutant Leader sends to news stations bearing his threats. This blackening, however, occurs in the context of a world enmeshed in the logic of colorblindness and multiculturalism. Whereas the visual contrast between black and white spaces readily corresponded to moral contrast between black and white people in the midcentury noir, 1980s racial logics required somewhat different operational language. Indeed, the text offers a sense of racial ambiguity, which has the effect of sublimating its commentary on race and criminality. Batman outfits himself in darkness, enabling him to move around at night and hide in the shadows. In an almost perfect illustration of Fiske's formulation of the racialized zones, Batman's whiteness as Bruce Wayne enables free motion across the invisible boundaries that relegate the Mutants to Gotham's underbelly. Yet in Miller's depiction of the hero, his body suit is gray and his hood and accessories are blue and yellow. Ultimately, the representational strategies Miller employs to eschew explicit racial coding cannot altogether escape implicit signification that link and align blackness with threat and whiteness with safety. Batman's shades of gray suggest that moral certitude is a thing of the past. In order to effectively respond to the Mutant threat, Batman will need to inhabit the interstitial space between right and wrong.

In his confrontation with Batman in the second volume, the Mutant Leader is racialized through a variety of physiognomic features that mark him as subhuman. He is painted with a gray pallor and spikes protrude from his head, neck, and wrist. His teeth are sharpened fangs, which, when coupled with his desire to "rip the meat" from Batman's bones and "suck them dry," mark him as a depraved cannibal. Indeed, the gang's name, "the Mutants," suggests that they are not humans at all, but are instead a different species 
altogether. Notably, this genotypic difference is not a source of empowerment as it is in Marvel Comics' $X$-Men series, but is instead presented as an atavism that precludes the members of the Mutants from social participation. Miller brings the two figures into close proximity in order to throw the differences between them into stark relief. Miller first demonstrates their physiological similarities. The Mutant leader's form and frame mark him as both dangerous and enticing. Batman leaves the relative safety of the Batmobile to test his strength against the Mutant Leader, to see how he rates against a figure he can't help but identify with. But the similarities between the two are few; whereas Batman uses the fear-inspiring cape and hood to augment his physicality, the Mutant leader's fangs and spikes are permanent features, marring rather than accentuating his body. The Mutant Leader is a manifestation of the cancer that plagues Gotham, a figurative embodiment of social ill rather than social will.

If Miller's depiction of the Mutant Leader's body is one ingredient in his blackening, a second is the location of the narrative in particular spaces. After losing a hand-to-hand fight against him in the Gotham City dump, Batman regroups and draws the Leader into a second fight, this time in the runoff of a sewer pipe near Gotham City jail. The Mutant leader moves from the dump to a jail cell, down through a drain to a pit of filth. The elision between the waste, wastefulness, and "ghetto" life that Jennifer Nash has recently described is instructive. Here, what is wasteful, as Batman signals as he literally scopes-out the Mutant Leader, is the latter's embodied capacity (Nash 2014). The Mutant Leader's natural inclination to the filth and darkness present Batman with the perfect trap, a pit of sewage beyond the view of state powers. Batman must follow him into each of these zones, and these forays draw him deeper into danger of falling victim to the criminal element associated with them. But this danger is superficial, and Batman is protected from the threat of contamination by his wealth and whiteness. Like Goetz, Bruce Wayne is immune from the stigma of criminality even though he is a criminal himself. In his second fight with the Mutant Leader, Batman dismantles him in the mud, using a combination of submission moves and pressure points to weaken and embarrass him before his assembled gang.

Batman ultimately defeats the Mutant Leader. In the aftermath, the gang splinters; some take up the mantle "the Sons of Batman" and act as a rag-tag vigilante group. Eventually, Bruce Wayne collects his supporters and leads them into the cave system beneath Wayne Manor, intending to marshal them into a vigilante force, a force "to bring sense to a world plagued by worse than thieves and murderers..." (Miller 1986). Bruce's operations undoubtedly continue to be subterranean. Rather than reunite with Gordon and seek the rehabilitation of his city in the light of day, Bruce instead opts for the shadows, cementing firmly a mistrust of the licit institutions designed for public safety.

\section{Conclusion}

The Washington Post explained, "when people feel they are not adequately protected, the force of the argument that they should not take their defense into their own hands diminishes" (The Washington Post 1984). The "failure" to provide adequate protection for the people who rode the subway was seen not as indication of the failures of state retrenchment or the rollback of infrastructure spending, but instead as evidence of insufficient law and order (The New York Times 1985a). Despite officials like Governor Cuomo and Commissioner Ward pressing for the importance of due process, the Post and others argued that state institutions could not adequately handle the issues of crime and criminality. Instead, the vigilante spirit emerged as the mechanism most capable of dealing with crime and criminality. As I have suggested, the vigilante spirit rested at the intersection of real and imagined manifestations of security problems. In his own confession, Goetz disavowed his relation to the imaginary figures of revenge that seemed to script his behavior: “... It's not Clint Eastwood [... or ] that movie Death Wish, [...] it's not being judge, jury and executioner..." (Caws and Shear 1987). Yet, the immediate and frequent reference to Death Wish reveals the ease with which Goetz's attacks mapped onto extant cultural fantasies of retributive violence. Bernhard Goetz's attacks were not, however, revenge fantasies in the spirit of Dirty Harry or Paul Kersey; they were manifestations of the assumption of criminality, racialized and racist assumptions of immanent 
danger. Race thus played a central role in scripting the Goetz drama, as it dictated which passengers were understood to be innocent and which were presumed guilty. Despite the efforts to disavow the fantastic elements and racial logics that guided the drama, their presence and prevalence in both the Goetz case and The Dark Knight Returns are undeniable. Exploring the operations of such elements demonstrates the powerful ways in which the vigilante spirit enabled racial violence in the moment of colorblindness.

In my analysis, I have linked the vigilante spirit to racist thoughts and feelings that mobilized specific actions that came to be protected under the banner of security. This kind of racism is, perhaps, more subtle than that practiced by the Klansmen Benjamin Ward mentioned in his remarks on the vigilante spirit, but it nevertheless relies on surveillance as a tactic for identifying and responding to security threats (Purnick 1985). Whether in the guise of Bernhard Goetz or Batman, the presumption of guilt that attaches to black and brown bodies through formal and informal surveillance enables the violent oppression of people of color. As recent history has indicated, the vigilante spirit has not waned. Instead, it has become institutionalized, enabling various policies including the War on Terror, which evolved directly out of the War on Drugs, as well as providing legal justification for attacks on black people like Eleanor Bumpurs, Rodney King, Trayvon Martin, and Tamir Rice, to name only a few. As more and more young men and women are unlawfully detained, beaten, and killed by citizens and police officers alike, there seems to be an urgent need to adequately account for the mobility and pervasiveness of such racialized distinctions between innocence and guilt. My interest here has been to think about the cultural contours of such a history, to explore how the social and cultural influence one another, and to examine what the effects of those influences might be. The imaginary parameters of racism and surveillance as they appear in The Dark Knight Returns evoke their more subtle manifestation in the real world drama that emerged in the wake of Bernhard Goetz's attack on the subway. The justification he provided consistently throughout, from his initial confession through each phase of the trial, defined young black men as threats and linked them to criminality. The public's acceptance of such logic stemmed from a shared sense of vulnerability, which illuminates the power of security imaginaries. Harnessing the power of security imaginaries could be the pathway to radical changes in the way we construe threats and propose responses. If security is speculative, then perhaps the best way to seek transformation is not legal or political agitation, but is instead through the production of new imaginaries in the cultural sphere.

\section{Acknowledgments}

The author wishes to thank Melani McAlister, Jennifer C. Nash, Gayle Wald, Ruth Feldstein, Megan Black, his writing partners at George Washington, Simone Browne, Ronak Kapadia, Katherine McKittrick, and the two anonymous reviewers for their scholarly insight and encouragement.

\section{References}

Alexander, Michelle. 2012. The New Jim Crow: Mass Incarceration in the Age of Colorblindness. New York: New Press. Anker, Elisabeth. 2015. Orgies of Feeling: Melodrama and the Politics of Freedom. Durham, NC: Duke University Press.

Avila, Eric. 2004. Popular Culture in the Age of White Flight: Fear and Fantasy in Suburban Los Angeles. Berkeley, CA: University of California Press.

Banzhaf, John F., III. 1985. "It is not 'Vigilantism.' It is Self-Defense.” The Washington Post. 12 January, A19.

Berlant, Lauren. 2011. Cruel Optimism. Durham, NC: Duke University Press.

Bonilla-Silva, Eduardo. 2014. Racism without Racists: Color-blind racism and the Persistence of Racial Inequality in America. New York: Rowman \& Littlefield Publishers, Inc.

Browne, Simone. 2015. Dark Matters: On the Surveillance of Blackness. Durham,NC: Duke University Press.

Butler, Judith. 2006. Precarious Life: The Powers of Mourning and Violence. New York: Verso.

Caws, Henri and Lisa Shear. 1987. The Confession of Bernhard Goetz. Orland Park, IL: MPI Home Video. Youtube. https://www.youtube.com/watch?v=PNSLht-OcRo.

Chambers, Marcia. 1985a. “Goetz Held at Rikers I. in \$50,000 Bail in Wounding of 4 Teen-Agers on IRT.” The New York Times. 4 January, B1.

1985b. "Goetz Rejects Offers on Bail From a Stranger and Family." The New York Times. 5 January, 25.

1985c. "Plea by Goetz is Not Guilty to Attempted Murder of 4." The New York Times. 29 March, B3.

Cobb, Charles. 1985. "Who is Bernard Goetz?" Afro-American. 16 February, 4.

D’Amato, Alfonse. 1985. "New York’s Empathy for Bernhard Goetz.” The New York Times. 9 February, 22. 
Fawaz, Ramzi. 2015. The New Mutants: Superheroes and the Radical Imagination of American Comics. New York: New York University Press.

Fiske, John. 1998. "Surveilling the City: Whiteness, the Black Man and Democratic Totalitarianism." Theory, Culture \& Society 15(2): 67-88.

Geist, William E. 1985. “About New York: Covering the Case of Bernhard Goetz.” The New York Times. 12 January, 25.

Giglio, Ernest. 2014. Here's Looking At You: Hollywood, Film \& Politics, $4^{\text {th }}$ edition. New York: Peter Lang Publishing.

Gordon, Avery. 2008. Ghostly Matters: Haunting and the Sociological Imagination. Minneapolis: New University of Minnesota Press.

Gunn, James and Matthew Candelaria. 2005. Speculations on Speculation: Theories of Science Fiction. Lanham, MD: Scarecrow Press.

Hale, Grace Elizabeth. 1998. Making Whiteness: The Culture of Segregation in the South. New York: Pantheon Books.

Hartman, Saidiya. 1997. Scenes of Subjection: Terror, Slavery and the Making of Nineteenth-Century Slavery. New York: Oxford University Press.

Holland, Sharon. 2000. Raising the Dead: Readings of Death and (Black) Subjectivity. Durham, NC: Duke University Press.

Hornblower, Margot, and Dody Tsiantar. 1985. "Symbol of Subterranean Vengeance, Suspect Returns to the Naked City." The New York Times. 4 January, A3.

Jameson, Fredric. 1981. The Political Unconscious: Narrative as a Socially Symbolic Act. Ithaca: Cornell University Press.

Kane, Bob, and Tom Andrae. 1989. Batman and Me, an Autobiography. New York: Eclipse Books.

Masco, Joseph. 2014. The Theater of Operations: National Security Affect from the Cold War to the War on Terror. Durham, NC: Duke University Press.

McGirr, Lisa. 2015. Suburban Warriors: The Origins of the New American Right. Princeton, NJ: Princeton University Press.

Miller, Frank. 1986. The Dark Knight Returns. New York: DC Comics.

Mitchell, Henry. 1985. "The Subway Shooting \& the Great American Verdict.” The Washington Post. 4 January, D2.

Nash, Jennifer. 2014. "Black Anality." GLQ: A Journal of Lesbian and Gay Studies 20: 439-460.

New York Times, The. 1984a. "Cuomo Condemns 'Vigilante Spirit'.” 27 December, B6.

. 1984b. "Warrant is Issued for Wounded Man." 28 December, B4.

. 1985a. "Gates, Guards, Guns and Goetz." 27 January, E20.

1985b. "Why Surrender on the Subway?" 4 January, A26.

Powell, Jody. 1985. “A Desperate Society.” The Washington Post. 3 January, A19.

Puar, Jasbir. 2007. Terrorist Assemblages: Homonationalism in Queer Times. Durham, NC: Duke University Press.

Purnick, Joyce. 1985. "Ward Declares Goetz Didn't Shoot in Self-defense.” The New York Times. 22 February, A1.

Rabinowitz, Paula. 2002. Black \& White and Noir: America's Pulp Modernism. New York: Columbia University Press.

Rieder, John. 2010. "On Defining SF, or Not: Genre Theory, SF, and History." Science Fiction Studies 37: 191-209.

Sanger, David E. 1984. "The Little-Known World of the Vigilante." The New York Times. 30 December, E6.

Schanberg, Sydney. 1985a. The New York Times. "Support Your Local Shooter." 5 January, 21.

_. 1985b. The New York Times. "The Bernhard Goetz Mailbag." 19 January, 21.

Schulman, Bruce. 2008. The Seventies: The Great Shift in American Society, Culture, and Politics. Cambridge: De Capo Press.

Sullivan, Ronald. 1989. "Goetz is Given One-year Term on Gun Charge." The New York Times. 14 January, 1.

Thompson, Kim. 1985. "Frank Miller: Return of the Dark Knight." The Comics Journal 101: 58-70.

Troy, Gil. 2005. Morning in America: How Reagan Invented the 1980s. Princeton, NJ: Princeton University Press.

Van Biema, David. 1985. "Dark World, Pale Hero-New Yorkers Rally Behind Subway Gunman Bernhard Goetz." People Magazine 23(3). 21 January.

Wacquant, Loïc. 2009. Prisons of Poverty. Minneapolis, MN: University of Minnesota Press.

Washington Post, The. 1984a. "On New York's Subway." 28 December, A16. . 1984b. "Vigilante Captivates New York." 28 December, A3.

- 1985. "Vigilante' Suspect Agrees to Return to New York City." 3 January, A14.

Wegner, Philip. 2009. Life Between Two Deaths, 1989-2001: U.S. Culture in the Long Nineties. Durham, NC: Duke University Press.

Williams, Raymond. 1971. Marxism and Literature. Oxford: Oxford University Press.

Williams, Patricia. 1991. The Alchemy of Race and Rights: Diary of a Law Professor. Cambridge, MA: Harvard University Press.

Woodward, Kathleen. 2009. Statistical Panic: Cultural Politics and the Poetics of the Emotions. Durham, NC: Duke University Press.

Wright, Bradford. 2003. Comic Book Nation: The Transformation of Youth Culture In America. Baltimore, MD: Johns Hopkins University Press.

Žižek, Slovaj. 2012. Mapping Ideology. New York: Verso. 